\title{
Haemangioma of the Tympanic Membrane and External Auditory Canal
}

S.V. Joshi. Lecturer, P.T. Wakode, Professor and Head, Department of E.N.T., Shri V.N. Govt. Medical College, Yavatmal-445 001.

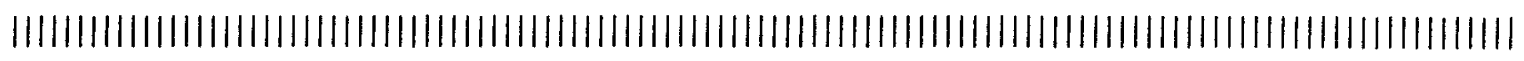

\section{Abstract}

An unusual case of haemangioma of external auditory canal in a 16 yrs. old male is documented for its rarity.

\section{||||||||||||||||||||||||||||||||||||||||||||||||||||||||||||||||||||||||||||||||||||||||||||$+||||||||||||||||||||$}

$\mathbf{S}_{\mathrm{r}}^{\mathrm{a}}$ anjay Wadde a 16 yrs. old male R/o. Yavatmal was admitted in E.N.T. Ward with complaints of discharge from left ear since two years and mass in ear canal since one month. On examination there was a polypoidal mass coming out from left external auditory canal. On probing it was found to be attached to its posterior wall. The tympanic membrane was not visible. X-rays showed sclerotic mastoid on the left side and paeumatised mastoid on right side.

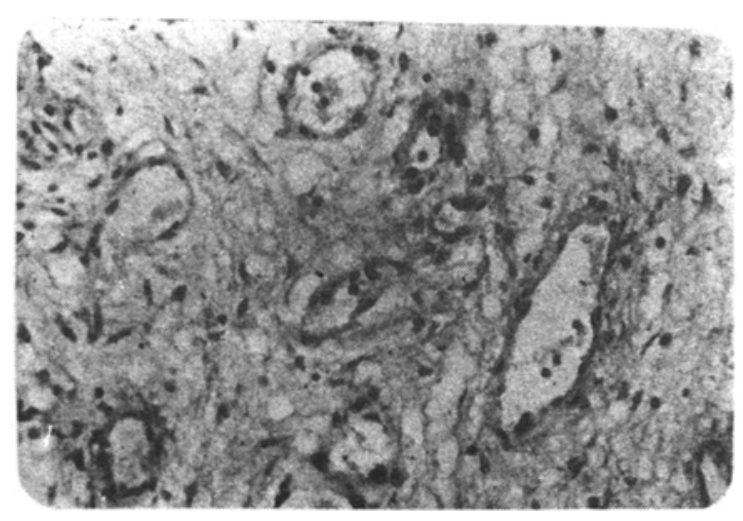

Fig. Photomicrogram
Patient was taken for surgery. He had profuse bleeding mass in the left external auditory canal with a broad based attachmet over the posterior bony part of the external auditory canal and the attachment was extending over to the adjacent tymanic membrane.

Whole mass along with a margin of surrounding skin was removed. Mastoid was explored. It was sclerotic. The antrum, aditus and attic did not reveal any disease.

Subsequent histopathology showed many vascular spaces with blood. The intermidiate tissue was sparse and showed occassional inflammatory cells, features suggestive of haemangioma, (Photomicrograph).

\section{Discussion}

Cavernous haemangiomas arising from tympanic membrane external auditory canal are rare. Freedman et-al reported first two cases located in the posterior bony meatal wall and the adjacent tympanic membrane. The middle 
ear was not involved. Balkany et-al (1978), Andrede et-al (1983) described single cases of cavernous haemangiomas of the tympanic membrane.
Even though such cases are a rarity they should be kept in mind because for the newcomers they may create problems.

\section{||||||||||||||||||||||||||||||||||||||||$|+|||||||||||||||||||||||||||||||||||||||||||||||||||||||||||||||||||||||$}

\section{References}

1. Andrede I.M., Gehri C.W., Brcitnecker R. (1983) Cavernous haemangioma of tympanic membrane. American Journal of Otology 4: 198-199.

2. Balkany T.J., Meyers A.D., Wong M.L. (1978) Capillary haemangioma of tympanic membrane. Archieves of Otolaryngology 104 : 296-297.

3. Freedman S.T., Barton S., Goodhill V. (1972) Cavernous haemangiomas of the tympanic membrane. Archieves of otolaryngology $96: 158-160$.

4. Kemink J.L., Graham M.D., MC Clatchey K.D. (1983) Haemangioma of external auditory canal. American Journal of Otology $5: 125-126$. 